\section{Agreement Needed on LIQUIDITY PROVISION TO RESTORE CONFIDENCE IN THE EUROZONE}

\section{Stefano Micossi*}

Some eighteen months after the first Greek rescue (May 2010), there is little doubt that the multiple attempts at crisis management in the eurozone have failed to restore confidence. Indeed, following each round of emergency measures agreed by the eurozone summits, to date the situation has deteriorated (see Figure 1 for the widening spreads, over the German Bund, for sovereign borrowing in the eurozone). At the time of writing, contagion had spread beyond Spain and Italy to the core sovereigns, with France close to losing its triple A-rating and even Germany experiencing partial failure in a Bund auction on 23 November. Spreads are also opening up for Austria, Belgium, Finland and even the virtuous Netherlands. Meanwhile, the banking system across Europe is under increasing strain, with term funding all but closed for any bank with significant exposure to distressed sovereign debtors and the interbank market close to seizing up. Deposit withdrawals have surfaced in a number of large banks from the periphery. The euro has started to weaken in foreign exchange markets, narrowing room for a distinction between the eurozone debt crisis and the euro-currency crisis from which some observers drew comfort until recently.

These developments once again raise fundamental questions: what is not working? Why is it that dramatic changes in our policies and institutions within the eurozone are failing to halt the meltdown of confidence? Answers are needed, and fast, because the breakdown of the eurozone now appears a concrete possibility if we continue along this path. Rather than dwelling on the details of specific interventions, this * ASSONIME, Rome, The Centre for European Policy Studies
(CEPS) and College of Europe. essay concentrates on the fundamental questions and disagreements before us. Essentially my argument is that political disagreements, rather than any fundamental economic disturbance, are leading us down a very slippery slope.

\section{Reform policies under way}

One important strand of opinion, notably in Germany and other northern European countries, maintains that the culprits behind the present crisis are lax fiscal policies and excessive debt accumulation by some eurozone member states. Greece, for one, is defaulting on its debt obligations, despite very harsh corrective measures - although its plight has been aggravated by its economy going into free fall as a result and its political system coming under almost unbearable strain in a bid to keep to the austerity course. But the numbers are small and should not endanger the solidity of Europe's banking system, even under extreme hypotheses of debt restructuring.

Ireland, Portugal and Spain have adopted or are about to adopt public-sector consolidation measures that have earned good marks from the European Commission, the European Central Bank (ECB) and the International Monetary Fund (IMF). Indeed their sovereign interest rate spreads over the German Bund were all receding - dramatically so for Ireland - up until the latest round of meetings by the euro summit at end-October (see Figure 1).

Last summer, sovereign selling pressures have expanded into Italy, which has a relatively small public sector deficit totalling about 4 percent of GDP in 2011, but a debt-to-GDP ratio of almost 120 percent. The government tried to play for time, but heavy selling pressures convinced it to bring forward budgetary balance to 2013. The limelight of market concerns then shifted to the adverse composition of the consolidation measures, largely based on higher taxes, and the absence of market opening and growth-enhancing measures, which in turn raised doubts about the longterm sustainability of the public debt stock, given Italy's endemic dismal growth and productivity per-

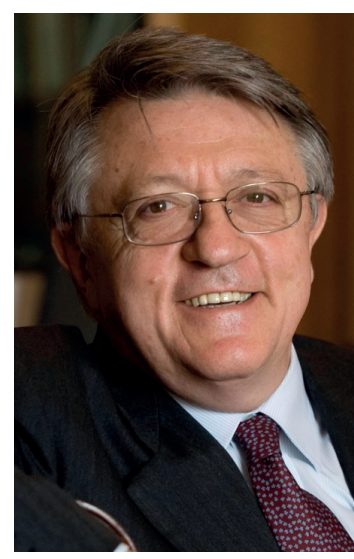


Figure 1

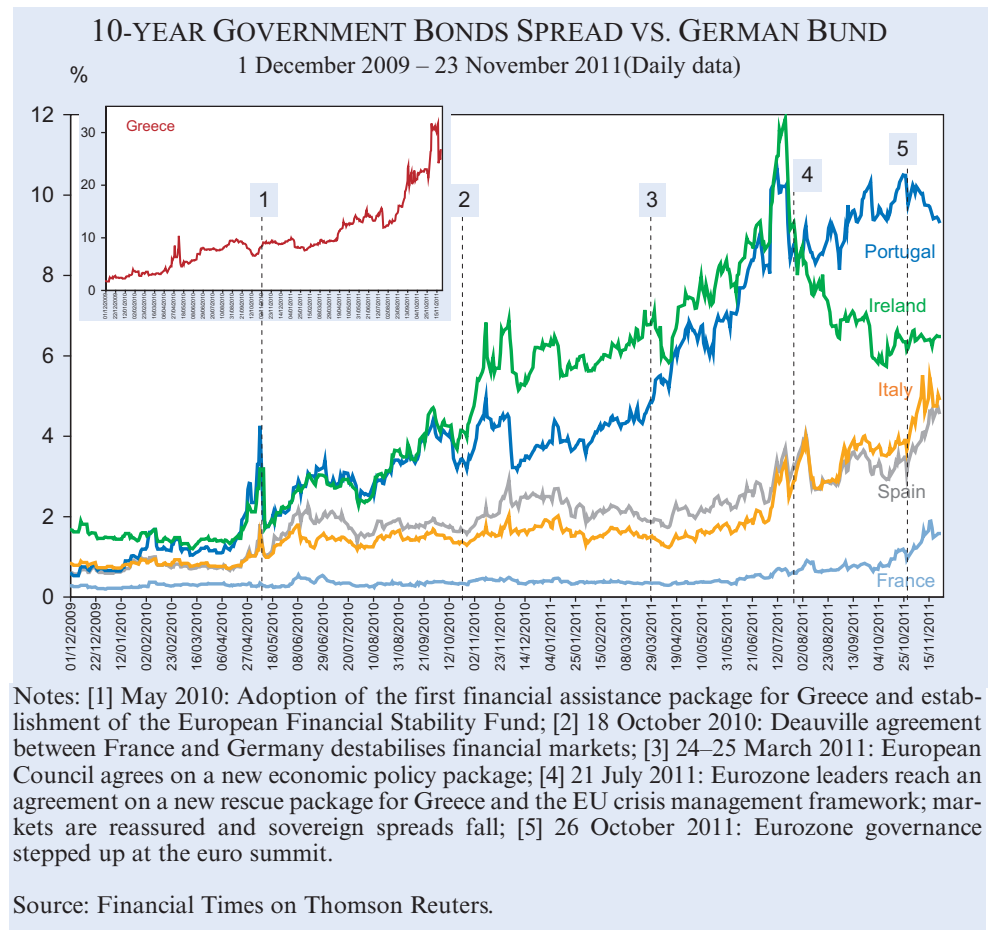

formance. Since Berlusconi's coalition was unwilling or unable to take steps required, it was ousted from government - once again under heavy selling pressures, with the spread over the Bund climbing to close to 600 basis points. The new 'national unity' Monti government, sworn in at lightning speed, has to date received broad parliamentary support for all measures needed to restore sound government finances and reform the Italian economy. The spread over the Bund has dropped, but it remains near 500 basis points as markets await the new government's decisions.

Currency union has admittedly allowed, or even encouraged, lax financial policies - with Germany and France carrying large responsibilities, having suspended in 2003 the excessive deficit procedure that should have been opened on themselves. These policies subsequently came to haunt all of us as financial markets re-priced sovereign risks. However, budgetary consolidation seems well underway in all 'sinning' countries, together with long-awaited structural reforms. As shown by Figure 2, IMF forecasts to 2016 suggest that after increasing in the aftermath of the 2008-09 financial and economic

Figure 2 crisis, sovereign debts are now expected to stabilise at manageable ratios to GDP in all of the eurozone countries except Greece, even though slow growth will not allow for rapid reductions. In sum, all available information points to a situation that is coming back under control.

\section{Stronger economic governance in the eurozone}

Meanwhile, economic governance in the eurozone has been strengthened to unthinkable degree in terms of both substance and enforcement procedures. The Broad Economic Policy Guidelines of Article 121 TFEU are now assisted by legally binding enforcement procedures, while the European Semester ensures ex-ante coordination of economic policies and timeconsistent decision-making processes in the member states and the European Council. The excessive deficit procedure has been reinforced in both its preventive and corrective arm and now includes fresh constraints on growth of public expenditures and operational criteria for public debt reduction. There is also a new procedure, also legally-binding and supported by sanctions, for the correction of 'excessive economic imbalances', explicitly targeting competitive imbalances and their underlying causes. The Euro-Plus Pact details the enhanced policy commitments of eurozone

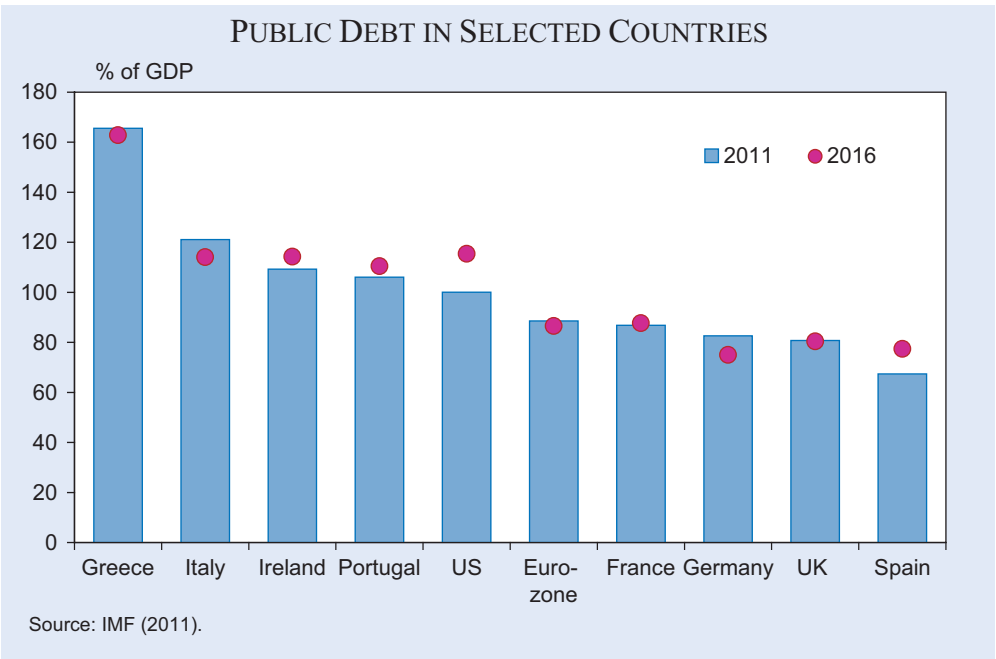


member states to budgetary stability, structural reforms and market opening. Eurozone members are required to strengthen their budgetary frameworks with the adoption of multi-year planning, top-down decision-making procedures and independent evaluation agencies. Many members have even indicated their intention to introduce balance-budget rules into their constitutions.

The European Commission has been given independent powers to signal emerging deviations from agreed policy guidelines, and to make recommendations to the Council on the opening of formal procedures, extending to the sanctions phase, which the Council can only reject or weaken with 'reverse' qualified majorities. A recently proposed regulation will require eurozone member states to present their draft budgets at the same time each year and, before national parliaments decide on them, give the Commission sufficient time to assess them and, if need be, ask for revisions when it considers that the draft budget violates the Stability and Growth Pact.

Some still consider these improvements insufficient and would like even stronger safeguards against policy slippages, possibly including the attribution of direct executive powers to eurozone bodies (to be identified) to modify policies within national domains. And yet, even leaving aside legitimate preoccupations regarding the progressive expropriation of national sovereign powers - which at some stage will clearly require the establishment of new legitimising controls at eurozone or Union level by means of treaty changes - there is little doubt that we now live in a different world where policy constraints on the member states of the eurozone are effectively binding, which is also due to additional coercion resulting from heightened financial markets scrutiny.

However, far from abating, market pressure on the eurozone still seems to be increasing. At the same time this pressure does not seem to be affecting countries with large deficits and rapidly rising debt outside of the eurozone, like the United States and Britain, not to mention Japan, which has mountainous public debt, totalling almost 200 percent of GDP, but seems to have no problems in placing its paper on the markets. Similarly, it is difficult, to understand why many countries with a smaller debt/GDP ratio than Germany within the eurozone like Austria, Finland or the Netherlands, for example, must pay a positive spread over the Bund on their government issues.
In the end, one only arrive at the conclusion that the eurozone suffers from some 'special disease' that makes financial markets fret even if policies seem on the right track everywhere. Of course, if this were indeed the case and a special disease did exist, it is also possible that the financial markets may be forcing us onto a path of excessive deflation, which may eventually frustrate all efforts at budgetary consolidation - Greece docet. ${ }^{1}$ This warning raises the question of the euro or, rather, the way we manage our common currency.

\section{The foreign currency syndrome}

The fundamental difference between a country that is a member of a monetary union and a country that has its own currency is that the former needs the permission of an institution that it does not control to increase liquidity, say to compensate for an outflow of liquidity through the banking system or to stabilise the government bond market, for example, while the latter does not. To each of the EMU members, for all practical purposes, the euro is like a foreign currency, since no one enjoys access to the euro printing press. As a consequence, eurozone member states are exposed to currency runs that are triggered when confidence in the ability to meet foreign-currency obligations is shaken by an exogenous shock or by unconvincing policies. Such a system can switch rapidly from 'fair weather', where foreign currency risks are underpriced, to 'bad weather' where risks become overpriced. In the second scenario, the explosion of financing costs can make fears of a run selffulfilling.

Switching from 'fair weather' to 'bad weather' is not an entirely unpredictable event. A further feature of monetary union is that one monetary policy must fit all - regardless of divergent prices and wages, productivity, public spending and taxation, and market openness. When a country with higher inflation and structural rigidities joins a monetary union, it typically finds itself awash with liquidity, since real interest rates become negative and credit is cheap. Of course, real exchange rates subsequently appreciate and business competitiveness suffers, leading to rising unemployment; but abundant credit encourages the country to postpone adjustment and preserve inefficient jobs with public money. Public spending rises as a result and the public-sector deficit widens, while

\footnotetext{
${ }^{1}$ Latin for 'teaches'.
} 
politicians will thrive on distributing subsidies and protection to broaden electoral consensus.

Lax financing conditions may prevail for quite a long time, as financial markets continue lending to divergent countries to gain higher nominal returns. Sooner or later, however, the process is bound to come to a halt, as growing external and public-sector deficits come to be seen as unsustainable. Then one day, typically as a consequence of some exogenous shock, investors flee, liquidity evaporates and the divergent country finds itself unable to refinance its debts in private markets at acceptable prices, as was the case with Greece and Portugal.

A variant of the model is one whereby the economy in the divergent country experiences a real-estate boom and rapid economic expansion, leading to unsustainable private indebtedness, while the public sector seems in good health. Here again, however, the realestate boom must end at some time, and, when house prices start falling, many of those private debts cannot be serviced, to the point where financing institutions are threatened with insolvency. In such cases the government may feel obliged to step in and rescue the banks, turning unsustainable private debt into dangerously high government debt, as happened to Ireland and, to a lesser extent, Spain.

Thus, lax and divergent national policies do carry responsibility for the sudden switch in confidence. However, financial markets do not tend to adjust smoothly, but rather by jumps, and they tend to overshoot. Even countries that did not run divergent policies or, at any rate, maintained manageable exposures in 'fair weather', may find themselves unable to manage them after the shift to 'bad weather'.

These events lead to a reassessment of outstanding risks for the entire union, with an extra ingredient: namely, the fact that national banking systems have in the meantime become highly interconnected - with 'core' country banks extending excessive credit to divergent country banks and governments. Thus any doubts regarding the sustainability of sovereign obligations in divergent countries are readily transformed into doubts over the sustainability of the banking system in the core, stable countries.

Confidence in financial markets is a fickle commodity that can evaporate quite rapidly unless investors can be reassured that a liquidity crisis will not be allowed to develop into a solvency crisis that spreads from one member of the monetary union to another. This is precisely what has happened in the eurozone since Greece was first bailed out in May 2010.

\section{Liquidity support and debt restructuring}

A confidence crisis spreading contagion even to the 'sound' part of a monetary union can be stopped by an abundant supply of liquidity from the central bank or by a common fund performing the same service but incorporating policy conditionality, with resources lent by the central bank or raised in the capital markets. In all likelihood, a suitable combination of both is currently needed. Failure by the euro summit to agree on a strong and effective rescue fund has stiffened the ECB, which fears that losses on its holdings of distressed sovereigns may one day force it to turn to national governments for capital, and thus lose its independence.

However, two stumbling blocks have so far impeded adequate liquidity support. The first impediment is the fear that liquidity will reduce pressure on 'sinners' to adjust. All assertions that the sinners are now mending their ways, under much strengthened common economic governance arrangements, have so far failed to convince the capital markets - even if, as I mentioned, policies have turned in the right direction everywhere. Some will not be satisfied until the union is assigned direct powers to intervene and change national policies whenever these deviate from their policy commitments. However, everyone should be aware that even the best policy course will need time to produce its effects; in the meantime, adequate financing flows must be maintained, or adjustment policies will fail to prevent a currency run.

The second ingredient in the unfolding drama is the intermingling of liquidity support and fiscal transfers, which inevitably arises if some of the countries under life support become insolvent and thus require debt restructuring. In this regard, Germany is adamant that liquidity support can never entail fiscal transfers - which would breach the 'no bail-out' provision of the Treaty (e.g. Article 125 TFEU) - and has on this account maintained strong pressure on the ECB to limit its open market operations in support of distressed sovereigns.

In reality, if adjustment works, there is no reason why liquidity support should be turned into fiscal transfers. To the extent that confidence is hit by fears of 
insufficient liquidity, the simple act of restoring adequate liquidity would stop the run and make insolvency, and the need for fiscal transfers, unlikely. On the other hand, if there is a collapse of liquidity, fiscal transfers may become inevitable at least to rescue own (German) banks, following the chain-collapse of all other sovereign debtors in the union.

Germany has also insisted that the private sector should share the burdens of any debt restructuring. As a result of disastrous communications, private sector involvement (PSI) has become a promise of losses on all outstanding eurozone sovereign exposures, without sufficient differentiation. Thus investors have started to shy away from most eurozone sovereigns; even Germany has been affected. A cursory look at Figure 1 will confirm that contagion really started following the Franco-German announcement in Deauville in October 2010 that PSI would be part of any financial assistance programme.

Two further jumps in the spreads are clearly associated with the July and October 2011 meetings of the euro summit, as the announcements of rising 'haircuts' on Greek debt combined with inadequate liquidity support for the other distressed debtors succeeded in convincing investors to get rid of eurozone sovereigns as rapidly as possible.

\section{Conclusion}

The eurozone has proven collectively unable to ringfence the Greek problem to date and to raise credible liquidity walls around the other distressed sovereigns. Meanwhile, the costs of adjustment in divergent countries are ballooning thanks to rising interest rates and falling activity, heralding further budgetary cuts and further deflation. The euro summit has to go back to the drawing board and overcome its political disagreements on how to proceed. Straitening policies in all the member states will not suffice; there is also a need for an adequate provision of liquidity - as large as needed to stop the on-going currency run. If this cannot be agreed upon, the eurozone will break up, creating gigantic economic dislocations as a result. 